OPEN ACCESS

Edited and reviewed by: Frontiers in Microbiology Editorial Office,

Frontiers Media SA, Switzerland

${ }^{*}$ Correspondence: Karina Y.-H. Gin ceeginyh@nus.edu.sg

Specialty section: This article was submitted to Antimicrobials, Resistance and Chemotherapy,

a section of the journal

Frontiers in Microbiology

Received: 25 January 2018 Accepted: 25 January 2018 Published: 05 February 2018

Citation:

Ng C, Tay M, Tan B, Le T-H, Haller L, Chen H, Koh TH, Barkham TMS, Thompson JR and Gin KY-H (2018)

Corrigendum: Characterization of Metagenomes in Urban Aquatic Compartments Reveals High Prevalence of Clinically Relevant Antibiotic Resistance Genes in Wastewaters. Front. Microbiol. 9:175 doi: 10.3389/fmich.2018.00175

\section{Corrigendum: Characterization of Metagenomes in Urban Aquatic Compartments Reveals High Prevalence of Clinically Relevant Antibiotic Resistance Genes in Wastewaters}

\author{
Charmaine $\mathrm{Ng}^{1}$, Martin Tay ${ }^{2}$, Boonfei Tan ${ }^{2}$, Thai-Hoang $\mathrm{Le}^{3}$, Laurence Haller ${ }^{1}$, \\ Hongjie Chen ${ }^{1}$, Tse H. Koh ${ }^{4}$, Timothy M. S. Barkham ${ }^{5}$, Janelle R. Thompson ${ }^{2}$ and \\ Karina Y.-H. Gin ${ }^{1,6 *}$ \\ ${ }^{1}$ Department of Civil and Environmental Engineering, National University of Singapore, Singapore, Singapore, ${ }^{2}$ Centre for \\ Environmental Sensing and Modeling, Singapore-MIT Alliance for Research and Technology Centre, Singapore, Singapore, \\ ${ }^{3}$ Department of Environmental Engineering, Ho Chi Minh City International University, Ho Chi Minh City, Vietnam, \\ ${ }^{4}$ Department of Pathology, Singapore General Hospital, Singapore, Singapore, ${ }^{5}$ Department of Laboratory Medicine, Tan \\ Tock Seng Hospital, Singapore, Singapore, ${ }^{6}$ NUS Environmental Research Institute, National University of Singapore, \\ Singapore, Singapore
}

Keywords: comparative metagenomics, antibiotic resistant genes, wastewaters, hospital, municipal, water body, tributary, beta lactamase resistant genes

\section{A corrigendum on}

Characterization of Metagenomes in Urban Aquatic Compartments Reveals High Prevalence of Clinically Relevant Antibiotic Resistance Genes in Wastewaters by Ng, C., Tay, M., Tan, B., Le, T.-H., Haller, L., Chen, H., et al. (2017). Front. Microbiol. 8:2200. doi: 10.3389/fmicb.2017.02200

Janelle R. Thompson was not included as an author in the published article. The authors apologize for this error and state that this does not change the scientific conclusions of the article in any way.

The original article has been updated.

\section{AUTHOR CONTRIBUTIONS}

CN wrote the manuscript and TK and TB provided clinical wastewater samples. CN, T-HL, LH, and $\mathrm{HC}$ conducted sampling and performed the experiments. CN, MT, and BT analyzed datasets. JT provided computational resources and supervision for data analysis. CN, MT, BT, and KG conceived and designed the experiments.

Conflict of Interest Statement: The authors declare that the research was conducted in the absence of any commercial or financial relationships that could be construed as a potential conflict of interest.

Copyright () $2018 \mathrm{Ng}$, Tay, Tan, Le, Haller, Chen, Koh, Barkham, Thompson and Gin. This is an open-access article distributed under the terms of the Creative Commons Attribution License (CC BY). The use, distribution or reproduction in other forums is permitted, provided the original author(s) and the copyright owner are credited and that the original publication in this journal is cited, in accordance with accepted academic practice. No use, distribution or reproduction is permitted which does not comply with these terms. 